\title{
A RECUSA DA "RACA": ANTI-RACISMO E CIDADANIA NO BRASIL DOS ANOS $1830^{*}$
}

\author{
Celia Maria Marinho de Azevedo \\ Universidade Estadual de Campinas - Brasil
}

Resumo: O objetivo geral deste artigo é chamar a atenção para a associação paradoxal das categorias de raça e racismo. Para isso buscaremos conhecer o antiracismo brasileiro em seus inícios durante os agitados tempos da Regência, nos anos 1830, época em que o termo "raça" ainda não havia se instilado em nossas mentes como uma "verdade" científica num sentido biológico ou cultural. Como veremos, lutar contra o "preconceito de cor" e pela cidadania significava recusar em definitivo o reconhecimento público da "raça".

Palavras-chave: anti-racismo, cidadania brasileira, racismo, Regência.

Abstract: The aim of this article is to call attention to the paradoxical linking between the concepts of race and racism. Having this in mind, my attempt is to visualize the early history of Brazilian anti-racism during the turbulent 1830's. By this time, presently known as the Era of Regency, the word race was yet far from being instilled in one's mind as a scientific truth either in biological or cultural terms. As we shall see the struggle against "prejudice of color", and in defense of citizenship, pointed toward the rejection of the public recognition of "race".

Keywords: anti-racism, Brazilian citizenship, racism, Regency Era.

Nunca se ouviu falar tanto em raça e racismo no Brasil - ou pelo menos não se ouviu falar tanto nos últimos 50 anos - como temos ouvido nos últimos

\footnotetext{
* Versões iniciais deste artigo foram apresentadas em 2004 em conferência no XIV Encontro Regional de História da Anpuh, em Juiz de Fora, Minas Gerais (28 de julho); em palestra no Centro Histórico Mackenzie, em São Paulo (4 de novembro); e em mesa-redonda no seminário "Multiculturalismo e Ações Afirmativas", do Programa de Pós-Graduação em Sociologia da Universidade de Brasília (13 de dezembro).
}

Horizontes Antropológicos, Porto Alegre, ano 11, n. 24, p. 297-320, jul./dez. 2005 
três anos, mais precisamente desde que se instalou o debate sobre a "cota racial” entre nós.

Como sabemos hoje, "raça" foi um termo corriqueiro na boca de grande parte das elites brasileiras que desde meados do século XIX saudaram as "descobertas” da ciência nessa matéria, produzidas em universidades da Europa e dos Estados Unidos. Desse momento em diante, o passado, o presente e o futuro da nação foram lidos a partir do pretenso potencial explicativo contido nesse termo. A categoria científica de raça ganhou tantos adeptos nesse período que mesmo aqueles que reconheciam a existência do "preconceito de cor" contra a população negra muitas vezes o faziam sem se desvencilhar da crença na existência de raças humanas.

Já o conceito de racismo foi cunhado bem mais tarde, provavelmente em meados dos anos 1920, quando alguns pensadores críticos do "preconceito de cor” e sensíveis às denúncias do movimento pan-africanista ascendente passaram a pensar sobre a categoria de raça, abandonando a postura tradicional de se pensar a partir dela, ou seja, dentro de seu pressuposto, e possibilitando, desse modo, o início da sua desnaturalização. ${ }^{1}$

É sempre bom lembrar que Casa Grande e Senzala foi escrito dentro desse novo espírito intelectual que buscava se liberar da categoria de raça, substituindo-a pela de cultura. Infelizmente esse movimento intelectual de desnaturalização do termo "raça” não se fez até o fim, persistindo até o nosso presente a ambigüidade no seu tratamento pelas ciências humanas. Explico: por um lado, afirma-se que as "raças humanas" não passam de uma construção racista de cientistas europeus e americanos cujos interesses associavamse direta ou indiretamente a grandes empreendimentos imperialistas na África, na Ásia, nas ilhas do Pacífico e naquilo que se convencionou designar por “América Latina”. Nada melhor aqui para sintetizar esse movimento conjunto do pensamento científico e das práticas colonialistas do que a frase lapidar de Hannah Arendt (1979, p. 183-184): se o racismo não existisse, o imperialismo o teria inventado. ${ }^{2}$ Mas por outro lado, as ciências humanas incorreram no pa-

${ }^{1}$ Sobre o aparecimento da palavra "racismo" em dicionários de língua inglesa e francesa, ver Miles (1989, p. 42) e Delacampagne (1983, p. 14).

2 Para uma visão crítica da investigação científica que tem como pressuposto o conceito de raça, ver Gould (1996), publicado no Brasil em Gould (2000). E, sobre a história do conceito de raça, ver Poliakov (1974).

Horizontes Antropológicos, Porto Alegre, ano 11, n. 24, p. 297-320, jul./dez. 2005 
radoxo de se pensar a história do racismo a partir da categoria de relações raciais, ou seja, o racismo seria compreendido à luz das relações entre "raças humanas".

Visto desse modo, podemos concluir que a história tem seus limites dados por categorias fora da história, ou a-históricas. O racismo se explicaria a partir de categorias dadas por natureza ou, quando muito, dadas por construções sociais imemoriais tão antigas quanto o próprio gênero humano. Sendo assim, o conhecimento da história nos serviria tão-somente para nos conformar ao que existe por natureza ou por uma espécie de história sem história, e jamais para nos liberar dos fardos inventados por nossos ancestrais.

É para esse ponto que eu gostaria de chamar a atenção dos jovens estudantes e profissionais que se iniciam nessa área de estudos que atravessa as ciências humanas, designada de forma insuspeitada de área de "estudos das relações raciais". Como disse, nunca se ouviu falar tanto em raça e racismo no Brasil como nos últimos tempos. Quanto ao racismo, é bom mesmo que se ouça, pois ainda hoje há aqueles que tratam o problema com uma certa condescendência, certos de que o Brasil se destaca por uma maior "tolerância” nas suas... "relações raciais"!

Mas é por aqui que devemos começar nosso questionamento crítico: vamos simplesmente incorporar essa categoria de raça em nossas análises, repetir mecanicamente que "as raças são uma construção social”, que elas impregnam já de longa data o nosso senso comum e por isso constituiriam uma realidade inescapável? Discutir se o Brasil tem sido mais ou menos tolerante historicamente em relação à "raça negra”? Ou então defender a criação de direitos de raça para a "raça negra”? Como historiadores e cientistas sociais, não será melhor compreendermos a construção localizada no tempo de uma categoria que não tem feito mais do que renovar o fardo perverso que nos foi legado pelas mentes ilustradas e racistas dos últimos três séculos?

O que me proponho aqui é chamar a atenção para esta associação paradoxal entre as categorias raça e racismo da qual infelizmente o anti-racismo do nosso presente não tem escapado, a despeito de suas intenções libertadoras em matéria de sofrimento humano. Para isso quero examinar o momento inicial do anti-racismo brasileiro na década de 1830, época em que o termo "raça” ainda estava longe de alcançar a sua "veracidade" científica a ponto de petrificar-se em nossas mentes como uma realidade irrecusável, venha ela em sua versão mais dura - a biológica -, ou então numa versão mais macia - a cultural. Já o termo "racismo", como disse acima, cerca de cem anos ainda transcorreriam 
antes que ele fosse cunhado. Mas a percepção de que o reconhecimento público das “raças humanas” gerava desigualdades políticas e sociais já encontrava algum poder de expressão na denúncia de "preconceito de cor" contra os cidadãos afro-descendentes, ditos "de cor”.

\section{A recusa do reconhecimento público das "racas"}

Os agitados tempos da Regência, na década de 1830, assinalam o antiracismo no seu nascedouro quando uma primeira geração de brasileiros negros ilustrados dedicou-se a denunciar o "preconceito de cor" em jornais específicos de luta, repudiando o reconhecimento público das "raças” e reivindicando a concretização dos direitos de cidadania já contemplados pela Constituição de 1824.

Bem pouco ainda conhecemos dos anos incertos da Regência, cuja sucessão de regentes, leis e contraleis, fazem até hoje a tortura dos colegiais em suas memorizações esquemáticas aprendidas de livros didáticos. O período iniciado em 7 de abril de 1831 com a abdicação de D. Pedro I em favor de seu filho de apenas 5 anos de idade e terminado em 1840 com o chamado "golpe da maioridade”, que permitiu a ascensão de D. Pedro II, foi batizado pelos historiadores de "Experiência Liberal”, ou ainda, "Experiência Republicana”. ${ }^{3}$ Como observou Marco Morel, esse período tem sido definido como "caótico, desordenado, anárquico, turbulento e outros adjetivos conexos” que mais confundem do que esclarecem aqueles que se aventurem a estudá-lo. Segundo ele, esse era "o discurso de parte dos grupos dirigentes da época” em suas disputas de poder no então nascente Estado nacional. Com a ascensão de D. Pedro II ao trono, os grupos dirigentes ascendentes buscaram formas de conciliar seus interesses de modo a consolidar o seu novo poder. Como sabemos, a história sempre pode ser um grande auxiliar dos governos na medida em que os historiadores se prestem a construir a memória apropriada ao fortalecimento e consolidação de seu poder. No caso, como observa este autor, os historiadores monarquistas do século XIX fixaram a descrição do período regencial nos termos daqueles adjetivos que conectavam a idéia de desordem. Com o tempo,

3 A respeito desses termos designativos do período da Regência, ver Castro, P. (1995) e Barman (1988). 
acostumamo-nos a tratar a Regência como um mero interregno entre os dois impérios, marcado por uma série de rebeliões derrotadas que não teriam tido grande importância a não ser lançar para um futuro distante as idéias republicana e federalista (Morel, 2003, p. 7-8).

Contudo, o que importa captar nesses agitados anos iniciais da Regência é o sentimento de indeterminação, de que tudo estava meio de pernas para o ar, enfim, de instabilidade de todas as instituições, perpassando todo o cenário político e social de um país tornado independente há apenas uma década. Foi, enfim, aquilo que Morel bem definiu como “o momento de explosão da palavra pública em suas múltiplas (e nem sempre tranqüilizadoras) possibilidades” (Morel, 2003, p. 10).

Entre os muitos temas perceptíveis nessa explosão da palavra pública destaca-se a disputa em torno do reconhecimento público das "raças". Mais de três séculos de dominação portuguesa haviam concorrido para erigir uma estrutura social de racialização explícita na forma de regimentos militares de pretos, pardos e brancos, de irmandades religiosas segregadas, de cemitérios separados, de estatutos clericais de pureza de sangue e também das restrições ao acesso de cargos públicos impostas àqueles com “defeitos de cor”. ${ }^{4}$

Havia, é certo, exceções gestadas pelas práticas sociais das colônias em seu dia-a-dia, momentos esses em que alguém conseguia "passar" para as esferas públicas dominantes, porém doravante “embranquecido” para todos os efeitos legais. Contudo, pode-se dizer que o Estado português, auxiliado pela Igreja católica, constituíra ao longo dos séculos de colonização uma sociedade escravista cujos segmentos livres da população organizavam-se em termos de uma hierarquia racial pública.

\footnotetext{
4 Ver a respeito: Boxer (1963, p. 116-117, 119); Degler (1986, p. 213-216) - publicado no Brasil (Degler, 1976); Carneiro (1988, p. 205-211); Serrão e Marques (1986, p. 224, 323-328, 348-350, 548) e, da mesma coleção, (1991, p. 300-304, 399). Degler chama a atenção para o fato de que muitas vezes essas leis segregacionistas vigentes na era colonial não eram aplicadas. Do mesmo modo, Silva (1986, p. 224) informa que muitos indivíduos conseguiam “dispensa do defeito de cor”, passando a ocupar cargos militares, civis e eclesiásticos que "por lei, só podiam ser desempenhados por brancos”. Contudo é, sem dúvida, significativo o fato de que para se escapar à hierarquia pública de raça era preciso obter efetivamente uma “dispensa do defeito de cor". Sobre os regimentos militares coloniais segregados, ver também Paula (1995, p. 265-277); o autor informa que Henrique Dias recebeu patente de "Primeiro Governador e Cabo dos Negros e Mulatos do Brasil" do Conde da Torre em 4 de setembro de 1639, e que no século XVIII subsistia na Bahia "o tradicional terço dos Henriques” (Paula, 1995, p. 266-267).
} 
O fato da "miscigenação", tão alardeado pela tradição historiográfica, não parece ter criado barreiras para a construção de uma sociedade segregacionista com amparo em leis as mais diversas. Assim, pode-se aventar, com base em inúmeras evidências dispersas em estudos históricos do período colonial, que os afro-descendentes, fossem eles libertos ou já nascidos livres, encontravam diversos impedimentos legais de teor abertamente racista diante de seus esforços para galgar os degraus superiores da escala social.

Há, é certo, muito a pesquisar a partir dessa perspectiva de uma sociedade colonial formalmente racista, na trilha aberta já de longa data por C. R. Boxer (1963). Contudo, o que importa reter aqui é o cenário de uma sociedade hierárquica em que a mobilidade social obedecia aos critérios de nascimento e de suposição de pertencimento racial e, apenas num segundo plano, aos critérios de mérito.

Podemos aventar que as disputas em torno da manutenção ou da demolição dessa hierarquia racial pública estiveram na raiz dos conflitos violentos entre portugueses e brasileiros já no início do movimento pela independência, em 1821. No imaginário nativista e popular, as descrições identitárias racializadas traduzem vividamente as rivalidades entre os "cabras", pretos ou pardos, ou seja, aqueles nascidos na terra, e os "marotos" ou brancos, os portugueses. Nos anos 1830, a crise política, acirrada pela partida de D. Pedro I e pelos conflitos subseqüentes entre “moderados”, “exaltados” e "restauradores”, permitiu novo fôlego às erupções nativistas, dessa vez acompanhadas de um franco debate sobre a cidadania e a identidade do brasileiro.

A historiografia tem se referido à emergência de um novo tipo de imprensa - a "imprensa mulata" - nos primeiros anos da década de 1830, destacando seus intuitos nativistas em defesa da população negra e mestiça livre. ${ }^{5} \mathrm{Contu}-$ do, ainda conhecemos pouco o conteúdo textual desta série de jornais cujos títulos são expressivos de um sentimento de auto-afirmação racial e de uma vontade de se contrapor à tradicional hierarquia racial pública associada com a colonização portuguesa. Entre eles, podemos citar: $O$ Crioulinho e $O$ Homem de Côr, tendo este último assumido o nome de O Mulato ou o Homem de Côr já em seu terceiro número, talvez para melhor expressar a figura do brasileiro capaz de integrar em si as “cores” da população, em vez de uma só cor.

5 A expressão “imprensa mulata” (mulatto press) está em Flory (1977, p. 208). 
Após analisar alguns de seus artigos, penso ser possível designá-los como um tipo de imprensa específica, voltada para a denúncia do preconceito racial e para a defesa da cidadania universal dos homens livres, o que significava lutar pelos direitos civis e políticos em parte já contemplados na Constituição de 1824. Preferiria, porém, deixar de lado a designação "imprensa mulata”, não só devido à carga preconceituosa já contida na origem do termo "mulato”, mas também porque, como veremos, a auto-afirmação da "cor" ou da "raça" parecia ser um recurso político momentâneo para se alcançar uma cidadania desracializada. ${ }^{6}$ Por isso acredito ser preferível designá-la nos termos de uma imprensa cidadã anti-racista.

A denúncia do tratamento desigual conferido aos cidadãos livres "pretos” e "pardos" destaca-se como uma preocupação central nas páginas de $\mathrm{O} H o$ mem de Côr e $O$ Crioulinho, os primeiros jornais dessa imprensa cidadã antiracista, fundados respectivamente em setembro e novembro de 1833. Ambos apresentam-se como "exaltados" e críticos das manobras do governo dos moderados, a quem acusam de procurar restaurar a antiga hierarquia pública de raça. É interessante que o editor de O Homem de Côr, Francisco de Paula Brito (1809-1861), tenha escolhido para estampar na capa de seu primeiro número duas colunas contrapostas: a primeira, à esquerda, reproduzia o texto da Constituição Política do Império em que se definiam os direitos civis e políticos dos cidadãos brasileiros - “Todo o Cidadão pode ser admitido aos cargos publicos civis, politicos, e militares, sem outra differença que não seja a de seos talentos, e virtudes"; já a segunda, à direita, reproduzia um trecho do ofício de 12 de junho de 1833 do presidente da província de Pernambuco, Manoel Zeferino dos Santos, no qual se afirmava a heterogeneidade do "povo do Brazil" e a inviabilidade da mistura de "classes” (O Homem de Côr, 1833). ${ }^{7}$

${ }^{6}$ Leon Poliakov (1974) chama a atenção para a carga pejorativa contida no termo "mulato", que começou a circular entre os europeus em meados do século XVII para designar o filho de branco com negro. Mulato vem de mulo (ou burro), isto é, filho de égua com jumento, ou de cavalo com jumenta (isto é, asno, jegue), conotando um ser híbrido e estéril. Ver, a respeito, Poliakov (1974, p. 111, 155). A militância anti-racista de homens negros de letras em defesa de uma cidadania desracializada foi abordada por mim em Azevedo (1998). Sobre essa mesma questão, ver Castro, H. (2000) e Grinberg (2002).

${ }^{7} \mathrm{O}$ artigo de abertura deste jornal defende a estrutura dessegregada e eletiva da Guarda Nacional, fundada há apenas dois anos. Sobre a Guarda Nacional e o sistema eletivo do seu oficialato, que desmanchava as linhas de cor entre oficiais e soldados, ver Castro, J. (1995); a autora observa que a Guarda Nacional foi "a primeira corporação oficial que fez cessar expressamente a distinção racial, o que a tornou essencialmente nova e revolucionária” (Castro, 1995, p. 282). Ver também Castro, J. (1979).

Horizontes Antropológicos, Porto Alegre, ano 11, n. 24, p. 297-320, jul./dez. 2005 
À primeira vista, as colunas não denotam nenhum debate sobre preconceito racial, pois de um lado apenas se menciona talentos e virtudes e, de outro, classes heterogêneas. Contudo, o artigo que se segue deixa claro que onde se lê "classes", deve-se entender "raças", e é a elas que o presidente de Pernambuco se referia ao tentar recompor a hierarquia militar, cujos cargos máximos haviam passado para "o povo dos ajuntamentos populares" em detrimento dos "habitantes pacíficos e que tem a perder". Como o redator de O Homem de Côr deixa claro, o intento do presidente moderado daquela província era criar batalhões segundo "os quilates da côr" - um de "intitulados brancos do Brasil, outro de mulatos, e outro de pretos"... Mas todos sabiam que a Constituição não distinguia "o roxo do amarello o vermelho do preto", pois com ela as distinções entre cidadãos ficavam por conta de seus talentos e méritos individuais. Por isso mesmo, cabia aos "exaltados" e também aos brancos não moderados unir-se em defesa da Constituição, pois agora "a balança” pendia "em favor das raças desprezadas bem que não despreziveis”.

Do mesmo modo, $O$ Crioulinho denuncia os intentos racistas dos chamados “moderados-jacobinos”, os quais, após a abdicação de D. Pedro I, passaram a usar o poder em favor de seus interesses e em detrimento das expectativas geradas pelo movimento conjunto de brasileiros brancos, pretos e pardos que culminou no "7 de abril”. Entre essas expectativas nutridas pelos “crioulos" (designados como pretos e pardos nas páginas desse jornal), e traídas pelos moderados ou "liberaes" brancos, destaca-se o direito ao trabalho. Os "chimangos" haviam-nos convidado a se unir às suas fileiras, "com o prazenteiro nome de Irmãos, e Cidadãos dignos de tudo; dizendo e protestando que marchavão firmemente a franquear-lhes a entrada para os primeiros Empregos Nacionaes”. Mas, desde então, "nunca mais appareceu hum Emprego para hum crioulo, e nem hum crioulo para hum Emprego. Contra factos não ha argumentos...”, concluía taxativamente o redator de $O$ Crioulinho. Não bastasse o fechamento dos postos de trabalho, presumivelmente em cargos públicos, aos cidadãos negros e pardos, havia ainda o tratamento jurídico desigual a que eles eram submetidos, como, por exemplo, o caso de um alferes preso juntamente com outros oficiais em um evento "político" de Ouro Preto. O alferes Custodio foi “o unico, que apezar da sua Patente, foi parar [n]a enchovia, misturando com facinoras - por nenhum outro mais, do que ser pardo!" (O Crioulinho, 1833, p. 3, grifo no original). ${ }^{8}$

8 “Chimango" quer dizer ave de rapina, conhecida também como carcará, caracará, ou gavião, conforme o dicionário Aurélio.

Horizontes Antropológicos, Porto Alegre, ano 11, n. 24, p. 297-320, jul./dez. 2005 
Diante dessas denúncias relativas aos atos políticos racistas dos "brancos” moderados recém-chegados ao poder de Estado, é interessante examinar a proposição acima de $O$ Homem de Côr: união de exaltados e brancos não moderados em favor de uma Constituição monárquica cega às “cores” de seus cidadãos e, portanto, a qualquer hierarquia pública de raças.

Em primeiro lugar podemos perceber que o termo exaltado designa aqueles que não são brancos, sem dúvida, “os mulatos e pretos” associados como membros da "raça desprezada”. Já os brancos, reconhecemos neles dois tipos políticos: os moderados, ou seja, os inimigos dos pretos e mulatos, tal qual "o branco Prezidente” da província de Pernambuco; e os não-moderados, aqueles que se aliam ao "homem de cor" em defesa da Constituição e, portanto, da cidadania universal para os homens livres.

Em segundo lugar, temos a associação dos termos "preto" e "mulato" com aqueles a quem "fingem-se cartas de liberdade quando há necessidade de "forças no Arsenal”; mas, "quando servidos; mulatos e pretos tomai vosso lugar, sois maioria atrevida, gente de xinelo e cacete” (O Homem de Côr, 1833, p. 2-3, grifo no original). Nessa breve passagem é possível perceber o sentimento de insegurança compartilhado pelos cidadãos brasileiros afro-descendentes. Se seus pais ou avós haviam conseguido emancipar-se, ou ainda se se tratasse de um liberto, isso não significava uma conquista definitiva para si próprios e seus descendentes, pelo menos não enquanto vigorasse uma hierarquia racial pública que os acorrentasse aos lugares mais ínfimos da sociedade, tal qual escravos.

Em terceiro lugar, encontramos uma associação clara entre os "exaltados” e a defesa da continuidade do regime monárquico de governo na medida em que se defendia a Constituição que lhes fora legada pelo império de D. Pedro I. A designação de "jacobinos", usada pelo redator de $O$ Crioulinho para se referir aos moderados no poder, salta à vista como uma referência histórica aos republicanos que sepultaram a mal-iniciada monarquia constitucional francesa após guilhotinar rei e rainha. Era portanto de um tipo de monarquia específico - a monarquia constitucional - que se tratava de defender nessas páginas escritas pelos exaltados “de cor”, críticos dos moderados com possíveis tendências republicanas e também dos "restauradores”, adeptos da monarquia absolutista ensejada por D. Pedro I.

Em quarto lugar, a defesa da Constituição pelos redatores dessa imprensa cidadã anti-racista deixa entrever uma omissão política deliberada, porém carregada de expectativa, em relação à escravidão e ao seu futuro. Isso porque, 
se, por um lado, a Constituição silenciava sobre a escravidão e, por conseguinte, sobre os escravos, por outro lado, o texto constitucional incluía os libertos nascidos no Brasil entre os seus cidadãos, prevendo-se implicitamente a continuidade das práticas de manumissão individual. Pode-se aventar, além disso, que ao reconhecer o liberto como cidadão brasileiro, a Constituição deixava margem para projetos legislativos de abolição gradual da escravidão, desde, é claro, que não colidissem com um dos direitos civis nela previstos, o direito de propriedade.

É interessante notar este apego à Constituição monárquica de 1824 entre aqueles que se apresentavam como "exaltados” e, portanto, radicalmente contrários à restauração do império de D. Pedro I. Havia, é claro, entre os "exaltados”, aqueles de tendência republicana radical, como foi o caso de Ezequiel Corrêa dos Santos, um desses líderes populares esquecidos da história da Regência. ${ }^{9}$ Mas, quando o nosso interesse se volta especificamente para a luta anti-racista emergente, o desafio é compreender o significado daquela Constituição entre aqueles que, tal como os republicanos radicais, defendiam direitos políticos e civis universais e, não obstante, apegaram-se à idéia de monarquia constitucional.

Como sabemos, a Constituição de 1824 passou para a história com o nome de "outorgada”, identificada como fruto de ato despótico de D. Pedro I. Insatisfeito com os rumos liberais dos debates constituintes, o imperador não só ordenou a dissolução da Constituinte de 1823, como fez prender e deportar diversos deputados. Contudo, sabemos que apesar de “outorgada”, a Constituição conservou itens básicos já debatidos e votados pelos constituintes, como, por exemplo, a definição de quem era cidadão brasileiro. ${ }^{10}$

\footnotetext{
9 Ver, a respeito, Basile (2001). Sobre o republicanismo popular emergente em diversas regiões do Brasil, com crescente apoio de escravos e negros livres, nas décadas de 1820 e 1830, ver Moura (1977). Outro liberal exaltado de tendência republicana foi Borges da Fonseca, editor de O Repúblico, no início dos anos 1830; ver Morel (2003, p. 22-24).

${ }^{10}$ Os libertos nascidos no Brasil, isto é, aqueles que saíram da condição de escravos, eram reconhecidos como cidadãos brasileiros, porém com direitos políticos restritos. De acordo com o Título 4, capítulo VI, artigo 94, os libertos eram excluídos do direito de ser eleitores de província, ou seja, do direito de votar na eleição de deputados, senadores, e membros dos conselhos de província; podiam, porém, votar nas assembléias paroquiais que elegiam os eleitores. Ver Campanhole et al. (1971). Sobre a questão da cidadania na Constituição de 1824, ver Grinberg (2002, cap. 3) e Oliveira (1998).
} 
Como já observei acima, o fato do texto constitucional reconhecer o liberto como cidadão, ou seja, alguém a quem se conferia direitos civis e políticos se bem que estes últimos parciais - deve ter pesado na balança das opções políticas daqueles empenhados em lutar contra o reconhecimento público das "raças" e em favor de uma política universalista cega às distinções tradicionais baseadas em nascimento e cor.

\section{A recusa do modelo de república dos Estados Unidos}

Além das experiências históricas locais, devemos também ter em mente a circulação dos relatos de experiências históricas recentes, ou mesmo contemporâneas àqueles que viveram os incertos tempos da Regência. O que quero dizer é que suas opções políticas moldavam-se também pelos modos como as histórias de outros povos eram apreendidas e assimiladas às questões políticas imediatas.

A trajetória de Francisco GêAcayaba Montezuma (1794-1870), deputado constituinte baiano, preso e deportado para Portugal em 1823, permite-nos visualizar como o aprendizado da história viva ou aprendida em livros traduziase em suas opções políticas. Após fugir do navio no qual viajava prisioneiro, Montezuma conseguiu chegar à França, tendo vivido nesse país e também na Inglaterra, Bélgica e Países Baixos, até voltar ao Brasil em 1831, por coincidência, na mesma data da abdicação de seu inimigo, o imperador. Montezuma, reconhecido herói da Independência e na sua qualidade de exilado, vítima do despotismo real, integrou-se rapidamente à comunidade política do Rio de Janeiro, atuando como deputado na Câmara menos de dois meses após seu retorno.

Assim como outros homens de letras afro-descendentes - na época chamados de pardos ou mulatos -, Montezuma não demorou muito para se associar às proposições políticas da corrente de exaltados favoráveis à monarquia constitucional, muito embora ele se definisse politicamente como "independente”. Em seu livro A Liberdade das Repúblicas, publicado em 1834, ele recorre profusamente à história passada e presente para persuadir o leitor de que a cidadania e, por conseguinte, a liberdade acabam fatalmente sufocadas pelo regime republicano. A começar pela epígrafe tirada do livro de Edmond Burke, Reflexões sobre a Revolução na França, publicado em 1790, podemos visualizar a adoção de uma postura respeitosa da tradição monárquica, porém não avessa a mudanças que trouxessem melhoria para o país. Nas palavras de 
Burke: "Uma disposição para preservar, e uma habilidade para melhorar, tomadas juntas, seria a minha posição em relação à Revolução na França” (Montezuma, 1834).

Em 1830, ainda no exílio, Montezuma teve a oportunidade de acompanhar a sublevação popular de Paris que expulsou os Bourbons do poder, abrindo caminho para um novo regime monárquico - a monarquia constitucional de Orléans. É possível que a nova Revolução Francesa de 1830 tenha reforçado neste antigo constituinte o horror ao despotismo monárquico, bem como a esperança de que o percurso constitucional interrompido pelos jacobinos há cerca de 40 anos pudesse ser retomado. Como sugere François Furet, Luis-Filipe I conseguiu tornar seu governo legítimo simultaneamente com base no Antigo Regime e na Revolução de 1789. Ao vincular as duas tradições liberais da história francesa, a da nobreza e a da burguesia, o filho do Duque d'Orléans girondino guilhotinado em 1793 e conhecido popularmente como "Filipe Igualdade” (Phillipe Égalité) - procurava restabelecer 1789 como um marco de união entre passado e futuro, de modo a impedir a eclosão de uma guerra civil no presente (Furet, [s.d.], p. 124). ${ }^{11}$

As expectativas de Montezuma com relação à nova monarquia francesa, revigoradas certamente pela leitura do antijacobino Burke, devem ter contribuído para alimentar suas reflexões sobre o cenário político revolucionado que ele encontrou em sua volta ao Brasil. Havia certamente alguma semelhança no fato de que também em seu país um reinado despótico terminara abruptamente sob pressão de um amplo movimento popular. Contudo, ao invés de um monarca constitucional, três regentes detinham o poder de Estado e já se distinguiam por seus atos tirânicos, conforme Montezuma denunciava enfaticamente, associando-se desse modo à oposição na Câmara e às vozes dos exaltados, onde quer que eles atuassem. ${ }^{12}$

\footnotetext{
${ }^{11}$ Aproveito para expressar aqui meu reconhecimento para com Margaret Jacob, que me chamou a atenção para o contexto revolucionário europeu na década de 1830, em carta comentando um artigo de minha autoria publicado anos atrás. A Revolução de Julho de 1830 marcou o fim do reinado de Charles X - "rei da França" - e deu início ao reinado de Louis-Philippe I - "rei dos franceses", conforme observa Lebédel (1999, p. 19-20).

12 Sobre essas denúncias, ver Francisco Montezuma (1832); o autor define-se como "independente" nesse livro. É possível que ao escrever este vigoroso libelo contra o governo dos “moderados”, Montezuma desse vazão implicitamente à suspeita de que uma de suas figuras máximas, o padre Diogo Feijó, estivesse a conspirar para implantar uma república.
}

Horizontes Antropológicos, Porto Alegre, ano 11, n. 24, p. 297-320, jul./dez. 2005 
Mas longe estava ele de querer se confundir com o movimento popular que já desenhava nas ruas a opção pela república. Talvez por isso mesmo ele tenha se dado ao trabalho de escrever um livro de mais de 350 páginas para persuadir a todos os "oposicionistas" da Regência de que a república acabaria no mesmo beco despótico da monarquia absolutista. Como ele explicava com base em inúmeros exemplos históricos tirados das repúblicas existentes desde a Antiguidade e até a era moderna, república e monarquia absolutista padeciam do mesmo mal, ou seja, de uma incapacidade de definir limites precisos ao poder executivo.

Nada melhor para provar a tese acima do que concluir o livro com um capítulo sobre os Estados Unidos, uma república proclamada há menos de 60 anos e que contava com muitas simpatias entre os exaltados. Sua Constituição de 1787 - aclamada como a primeira constituição escrita na história da humanidade - abria-se com palavras bem ao gosto do sonho iluminista de cidadania universal - "nós, o povo, [...] com vistas a formar uma União mais perfeita, estabelecer justiça, garantir a tranqüilidade doméstica, proporcionar a defesa comum, promover o bem geral e assegurar as bênçãos da liberdade para nós mesmos e nossa posteridade, ordenamos e estabelecemos esta Constituição para os Estados Unidos da América” (Morison, 1965, p. 292-304, tradução minha).

Mas a despeito do preâmbulo constitucional tão bem afinado com as Luzes dos filósofos do XVIII e com a vontade popular já expressa em diversos países do mundo, os Estados Unidos não faziam por merecer tão belas palavras. Ao contrário de suas promessas, muitos de seus habitantes ainda desconheciam os direitos civis e políticos mais elementares, emanados da concepção de igualdade natural dos seres humanos, aliás, constante também do preâmbulo da Declaração de Independência de 1776. Esse era o caso específico dos homens livres “de cor”, os quais viviam segregados, uma vez que estavam excluídos do direito de voto e dos diversos espaços de sociabilidade freqüentados por pessoas brancas, tais como igrejas, tavernas, escolas e sociedades literárias. Quanto aos escravos, eles eram tão cruelmente tratados pelos seus senhores que até mesmo o direito de constituir família lhes era negado. Nas palavras de Montezuma,

Se como disse Jefferson as duas raças branca e de cor, não podem viver juntas, e igualmente livres na Republica Federativa dos Estados Unidos, a Constituição da Monarchia Representativa do Brazil nenhuma distincção faz do homem branco, e 
do Homem de cor: todos são filhos do Pai: todos são igualmente Cidadãos do Estado; todos gozão dos mesmos Direitos. Se a Stabilidade daquela Republica exige que a Classe de cor seja opprimida e considerada verdadeiramente coisa, sem direitos nem politica consideração: a Monarchia Brasileira sufficientemente solida em suas instituições nada recea da mais illimitada IGUALDADE perante a Lei. (Montezuma, 1834, p. 364-367, grifo do autor). ${ }^{13}$

Para chegar a essas conclusões sobre a triste situação vivida pelas pessoas “de cor” nos Estados Unidos, Montezuma apoiou-se, entre outras fontes, no Apelo de Walker, um pequeno livro de autoria de um alfaiate negro, publicado em Boston em 1829, e que causou um grande impacto entre seus leitores brancos e negros. Nos estados do Sul, o alarme soou especialmente entre senhores de escravos, assustados com a possibilidade de que o livro chegasse de alguma forma às mãos dos escravos. Por isso, as autoridades sulistas passaram a revistar os porões dos navios vindos do Norte em busca do panfleto explosivo.

David Walker, filho de um escravo e de uma mulher livre, que havia migrado da Carolina do Sul para Massachusetts alguns anos antes, dirigiu seu apelo a "todos os homens, mulheres e crianças de cor de todas as nações, idiomas e línguas existente sob o céu”. Nesse apelo, Walker sugeriu três caminhos para destruir a escravidão e o preconceito de cor. O primeiro, a ser assumido pelos escravos, defendia o uso da violência contra os senhores na luta pela liberdade. Já o segundo caminho, o das pessoas negras e livres, era o de refutação do preconceito de cor, bem como das teorias que o amparavam, como por exemplo, a de que os negros originavam-se de "tribos de macacos e orangotangos”. Quanto ao terceiro caminho, ele cabia às pessoas brancas, cujo arrependimento poria fim à opressão das pessoas negras; em caso contrário, Deus lhes daria o fim terrível tão merecido. ${ }^{14}$

Montezuma aderiu certamente ao segundo caminho, pois em sua condição de homem livre “de cor” ele podia compreender bem o ensinamento central de Walker: se o preconceito era uma invenção dos brancos, sua reprodução dependia do fato dos negros continuarem submissos àqueles. Contudo, em sua defesa da monarquia constitucional, onde não haveria lugar para distinções públicas de cor e, portanto, para o preconceito que fere o cidadão publicamen-

\footnotetext{
${ }^{13}$ Além do capítulo sobre a república americana, há outros sobre as repúblicas da Grécia, de Roma, Veneza, Gênova, Genebra, e Helvética.

${ }^{14}$ Analisei o livro de Walker em Azevedo (2003a, p. 168-170).
} 
te, Montezuma descartou o caminho da insurreição dos escravos, tal como acenado por Walker.

É certo que a escravidão não combinava com quem acreditava na igualdade natural de todos os seres humanos, mas o que fazer em país de escravos, onde até mesmo Montezuma, assim como tantos outros homens brancos e negros de elite, tinham ou faziam uso de escravos? ${ }^{15}$

Além da preocupação com seus interesses econômicos, os quais iriam à ruína na falta do trabalho escravo, esses zelosos proprietários padeciam do medo do "haitianismo". A possibilidade de que o exemplo recente da vitoriosa revolução dos escravos do Haiti incendiasse a imaginação dos seus próprios escravizados já se fazia sentir em diversos focos de insurgência, os quais se agravariam ao longo da década de 1830, deixando entrever a perspectiva de fragmentação do império em diversas repúblicas. ${ }^{16}$

A saída para o problema da escravidão adotada pelos homens negros de elite que atuaram nesses primeiros anos da Regência encontra-se em esquemas graduais de emancipação, como foi o caso dos projetos apresentados por Montezuma e Antonio Rebouças, outro deputado “de cor” associado à oposição da Câmara ao governo da Regência. ${ }^{17}$ Além disso, ao defender a Constituição de 1824, criava-se a expectativa de que um número crescente de escravos pudesse adquirir por meios legais suas "cartas de liberdade”, o que lhes garantiria a condição de cidadãos brasileiros com direitos políticos restritos e, aos seus filhos, o apagamento público de suas origens servis. ${ }^{18}$

\footnotetext{
${ }^{15}$ A ex-mulher de Francisco Montezuma refere-se à propriedade comum de 14 escravos como uma das fontes de rendimento do casal, além de uma chácara e uma pedreira; ver: A Viscondessa... ([s.d.]). Grinberg (2002, p. 82, 93, nota 44) encontrou referência a dois escravos e dois “serviçais” de Antonio Rebouças em ofício de 1824; para vários exemplos de homens negros livres que se tornaram senhores de escravos, ver Libby e Paiva (2000).

${ }^{16}$ Sobre o tema do haitianismo ver, entre outros: Flory (1977, p. 199-224); Barman (1988, p. 192193); Castro, J. (1995, p. 283-284); Moura (1977, p. 134-142); Grinberg (2002, p. 48-58, 102); Soares e Gomes, (2002).

${ }^{17}$ Em 1832, Montezuma pronunciou-se contra o tráfico de escravos da África na Assembléia Nacional, o qual continuava a se fazer a despeito da sua proibição em lei de 1831, votada sob pressão britânica. Anos depois, em meados de 1850, já senador, membro do Conselho de Estado e ostentando o título de Visconde de Jequitinhonha, Montezuma apresentou projetos de abolição gradual da escravidão. Ele também esteve entre os primeiros políticos a exigir a abertura de debates sobre a abolição da escravidão no Parlamento, a partir de 1865. Ver, a respeito, Venancio Filho (1984, p. 7, 18). Em 1830, o deputado Antonio Rebouças apresentou projeto de manumissão de escravos (com pagamento de seu valor ao senhor); consultar Grinberg (2002, p. 119-124).

${ }^{18}$ Desenvolvi argumentos mais detalhados nesse sentido em Azevedo (1998).
} 


\section{Reflexões conclusivas}

Neste ponto podemos identificar dois legados paradoxais do anti-racismo brasileiro em seus anos iniciais. São eles: 1) a omissão em relação à continuidade da escravidão por tempo indeterminado; 2) a colocação dos primeiros tijolos na construção daquilo que conhecemos hoje como o mito do paraíso racial brasileiro.

Em relação ao primeiro paradoxo, devemos lembrar o legado do universalismo das Luzes entre os homens negros de letras que atuaram no período da Regência. É interessante observar que Francisco de Paula Brito e Francisco Montezuma eram ambos membros ativos da maçonaria, a qual recobrava visibilidade e se reorganizava rapidamente após anos de perseguição político-policial. ${ }^{19}$ Se é certo que na sua condição de homens “de cor”, ambos eram muito sensíveis à questão social do racismo, também se pode pensar que a sua qualidade de maçons os tornava especialmente empenhados em realizar o sonho iluminista de transpor a concepção abstrata de igualdade natural para uma política de cidadania em que as distinções individuais se fizessem tãosomente em termos de mérito (Jacob, 1991, p. 179, 204).

Nessa perspectiva, podemos compreender a defesa da Constituição de 1824 como a única garantia viável de que a hierarquia racial pública tradicionalmente vigente em terras brasílicas fosse rompida em definitivo. Em suma, o reverso da luta pelo não reconhecimento público das “raças" era a vontade de reconhecimento do princípio de cidadania universal.

Contudo, defender a Constituição de 1824 significava também apoiar a continuidade da monarquia cujos fundamentos mais sólidos eram o latifúndio e a instituição da escravidão. Com isso sacrificavam-se, numa cartada, as vidas de milhares de escravos, os quais continuariam indefinidamente acorrentados à propriedade escravista.

Havia, sem dúvida, paradoxo em se contrapor à hierarquia racial pública e ao mesmo tempo manter na escala mais ínfima dessa hierarquia aqueles que nem mesmo eram mencionados na Constituição. Ou seja, desfazia-se a hierarquia racial pública para os homens livres, mas não para os escravos ou simplesmente “os pretos”, como se dizia então.

\footnotetext{
${ }^{19}$ Sobre maçonaria, sociabilidade e perseguições político-policiais aos maçons no período da independência, ver Barata (2002). O tema da maçonaria e do Iluminismo foi analisado por mim em Black Freemasons and the Enlightenment (Brazil, década de 1830) (Azevedo, 2003b).
}

Horizontes Antropológicos, Porto Alegre, ano 11, n. 24, p. 297-320, jul./dez. 2005 
É a partir desse primeiro paradoxo do anti-racismo, isto é, o sacrifício das vidas dos escravos em prol dos direitos dos livres, que começa a se desenhar um segundo paradoxo, cuja presença infelizmente ainda hoje é perceptível no nosso imaginário. Quem visitasse os Estados Unidos em meados dos anos 1830 em diante, ou ao menos lesse os livros e artigos produzidos em círculos abolicionistas, encontraria uma comparação cada vez mais insistente sobre a escravidão nos Estados Unidos e no Brasil. Como explicou o ex-escravo e abolicionista Frederick Douglass em uma palestra em 1858 na cidade de Nova Iorque, no império brasileiro os homens “de cor”, livres ou libertos, eram cidadãos como quaisquer outros, pois "a sua cor e aparência perdem-se de vista em meio ao brilho de sua liberdade”. O contrário acontecia nos Estados Unidos: os escravos não contavam com nenhum direito de manumissão e as pessoas livres “de cor” não gozavam de direitos de cidadania, na medida em que inúmeras posturas legais recusavam direitos civis e políticos para pessoas vistas como pertencentes à "raça negra” (Douglass, 1979, p. 211-212).

A história da construção do mito do paraíso racial brasileiro é, sem dúvida, bem mais longa e intrincada do que pensávamos ao tratá-la simplesmente como uma dimensão do ufanismo nacionalista das elites dos anos 1930 e cuja expressão maior encontramos nas páginas cativantes de Gilberto Freyre.

Espero ter deixado claro, ao longo deste artigo, que as raízes do mito, ou, melhor dizendo, alguns dos primeiros tijolos de sua construção, foram lançados por aqueles que paradoxalmente empenharam parte de suas vidas em denunciar o racismo no Brasil na década de $1830 .{ }^{20}$ Minha sugestão aqui é que a luta contra o reconhecimento público das "raças", ao mesmo tempo em que deixava a escravidão intocada, contribuiu para consolidar a antiga prática cotidiana já observada na colônia - a de não mais se referir à cor daquele que conseguiu "passar" socialmente para o mundo dos de cima. ${ }^{21}$ Ao mesmo tempo, é possí-

\footnotetext{
${ }^{20}$ Outros tijolos para essa construção do mito do paraíso racial brasileiro foram lançados no bojo do movimento abolicionista nos estados do Norte dos Estados Unidos, como demonstrei em Azevedo (2003a).

${ }^{21}$ Hebe Maria Mattos de Castro chama a atenção para “o desaparecimento da menção sistemática da cor” em processos cíveis e criminais das décadas de 1850 e 1860. Segundo ela, em geral silenciavase sobre a cor, a não ser quando se tratava de fazer uma referência negativa a alguém. Mas, como ela explica, não se tratava simplesmente de uma vontade de branqueamento: "a cor inexistente" era “um signo de cidadania na sociedade imperial”, sendo a liberdade a sua única pré-condição; ver a respeito: Castro, H. (1995, p. 107-110).
}

Horizontes Antropológicos, Porto Alegre, ano 11, n. 24, p. 297-320, jul./dez. 2005 
vel afirmar que, no plano da intimidade, a crença no pertencimento racial continuou a pautar a relação cotidiana entre brancos e negros, crença essa muito reforçada pela rápida e vitoriosa difusão das teorias raciais científicas a partir da segunda metade do século XIX. Estava, portanto, aberto o caminho para o racismo que conhecemos hoje no Brasil, o racismo velado que raramente se explicita nas relações diretas entre pessoas, e o racismo institucional, ou seja, aquele que impregna as instituições sem apoiar-se explicitamente na categoria de raça. ${ }^{22}$

Em resumo, o problema central que se pode detectar nessa primeira geração de militantes do anti-racismo foi a sua postura ambígua ou mesmo conformista em relação à continuidade da escravidão. Sacrificavam-se as vidas dos muitos escravos então existentes em todo o país em nome de um sonho de mobilidade e ascensão social aberto a todos os homens livres e libertos. Mas o problema desse anti-racismo não era a sua postura universalista de ênfase no mérito individual, e sim o seu universalismo limitado que se detinha diante da escravidão para não ferir o direito à propriedade.

Neste ponto é interessante observar uma certa semelhança entre o antiracismo dos anos 1830, universalista, e o anti-racismo atual, diferencialista. Destaco dois aspectos:

Em primeiro lugar, nenhuma dessas modalidades de anti-racismo formula políticas para acabar com a desigualdade social naquilo que lhe é mais extremo, ou seja, a falta de propriedade entre muitos, contraposta à concentração de riqueza entre poucos.

Em segundo lugar, os dois tipos de anti-racismo postulam políticas que permitem a ascensão daqueles que já se afastaram da base da pirâmide social, mas se "esquecem" da maioria negra concentrada em seus degraus mais ínfimos. Em tempos da Regência, e durante o segundo Império, os "esquecidos" do anti-racismo universalista eram os escravos, e também os nacionais pobres livres, em sua maioria afro-descendentes. Em tempos presentes, os "esquecidos” do anti-racismo diferencialista são os habitantes das favelas, as pessoas sem teto, os trabalhadores sem terra, as crianças de rua ou internas em institutos penais, outra vez - e não por mera coincidência para quem conhece o racismo brasileiro - afro-descendentes em grande parte.

${ }^{22}$ Sobre o conceito de racismo institucional, ver Carmichael e Hamilton (1967) e Miles (1989). 
Desse modo, temos uma clara aspiração liberal a irmanar as duas tendências anti-racistas: a esperança perceptível em ambas é que "os debaixo" possam se espelhar "nos de cima”, e, na medida das "oportunidades”, possam ascender na pirâmide social do mundo capitalista. Em tempos da Regência e do Segundo Império, as “oportunidades” vinham da indulgência protetora das elites brancas no mesmo rol das redes clientelísticas essenciais para a reprodução de poderes locais. Em tempos atuais, as “oportunidades” contam com o empenho de patronos como José Sarney ou Garotinho para fazer passar políticas de ação afirmativa em que se concede uma cota protetora a um pequeno segmento de pessoas ditas de "raça negra”, que por seu próprio esforço e mérito já se afastaram dos patamares sociais mais ínfimos. ${ }^{23}$

Mas, em que pese os paradoxos de ambas as tendências, eu não poderia deixar de assinalar a importância ainda hoje da promessa irrealizada daquele primeiro momento do anti-racismo: a construção de uma sociedade capaz de ultrapassar a ficção das raças para concretizar o grande sonho iluminista de cidadania universal.

Essa observação ganha ainda mais pertinência no momento atual, quando vemos uma crescente tendência de militantes do anti-racismo de teor diferencialista sair em defesa do reconhecimento público da "raça negra" como forma de contra-atacar o racismo institucional vigente no nosso país. ${ }^{24}$

Em termos comparativos, mais uma vez, podemos dizer que enquanto a primeira geração de homens negros de letras lutou contra o racismo nos anos

${ }^{23}$ Muito apropriado o termo "neo-abolicionista” forjado por Edson Cardoso para se referir a essa nova patronagem sobre o movimento negro, que emergiu com força nos últimos anos. Para ele, o neo-abolicionismo tem engendrado "uma azeitada máquina de cooptação e infantilização dos negros”. Sem dúvida, é tentador construir aqui uma analogia com os abolicionistas de elite que nas últimas décadas da escravidão preocuparam-se com a transformação do escravo em trabalhador "livre" a serviço da grande propriedade capitalista. Ver o editorial de Edson Cardoso em Irohin (Cardoso, 2004); no mesmo número há diversos artigos que expressam preocupações semelhantes às minhas em relação à grande massa de cidadãos negros “esquecidos” nas periferias das nossas grandes cidades, nos acampamentos dos sem-terra, e nas terras quilombolas griladas. Ver em especial Santos (2004) e Cruz (2004). Sobre os abolicionistas e suas proposições controlistas, ver Azevedo (2004b).

${ }^{24}$ Analisei o debate interno do movimento anti-racista contemporâneo em Anti-Racismo e seus Paradoxos: Reflexões sobre Cota Racial, Raça e Racismo (Azevedo, 2004a). Esse debate continua e promete ganhar ainda muito fôlego conforme se pode perceber em artigo recentemente publicado de Marcos Chor Maio e Ricardo Ventura Santos (Maio; Santos, 2005). O livro de Patrícia Pinho (2004) traz também valiosa contribuição a este debate interno do campo do anti-racismo.

Horizontes Antropológicos, Porto Alegre, ano 11, n. 24, p. 297-320, jul./dez. 2005 
1830, buscando liberar-se do fardo histórico da “raça”, a geração atual de antiracistas luta para se liberar do mito da democracia racial brasileira. Quanto a isso, nenhum problema. Mas, será preciso repor o fardo da "raça”, onde houve tanto esforço anti-racista no sentido da sua desconstrução? Melhor seria nos desvencilharmos das vozes desumanas de nossos antepassados para, em seu lugar, introduzir a invenção na existência, tal como nos alertou Frantz Fanon, em sua defesa de uma autêntica comunicação humana (Fanon, 1971, p. 186). Era isso, precisamente, que os homens negros de letras que combateram o racismo nos anos 1830 pretendiam fazer a despeito de seus resultados paradoxais; ou seja, inventar uma sociedade em que a crença na igualdade dos seres humanos superasse as distinções associadas tradicionalmente com o nascimento ou com a atribuição de "raça".

A categoria de raça enquanto termo-chave das práticas racistas - abertas ou veladas - é um fardo da história do qual precisamos urgentemente nos liberar se ainda quisermos concorrer para o futuro da humanidade. Por isso mesmo, na minha condição existencial de historiadora, vejo como de suma importância a pesquisa em história do racismo e do anti-racismo. Afinal, penso que a história, ou melhor, a atividade do historiador, não se faz para incentivar conformismos, ou então simplesmente para divertir. Para mim a história é sempre uma atividade liberadora na medida em que nos faz pensar e cujo poder de comunicação é essencial para a atividade crítica das pessoas em sociedade.

\section{Referências}

ARENDT, Hannah. The origins of totalitarianism. New York: HBJ Book, 1979.

AZEVEDO, Celia Maria Marinho de. Maçonaria, cidadania e a questão racial no Brasil escravista. Estudos Afro-Asiáticos, n. 34, p. 121-136, dez. 1998.

AZEVEDO, Celia Maria Marinho de. Abolicionismo: Estados Unidos e Brasil, uma história comparada (século XIX). São Paulo: Annablume, 2003a.

AZEVEDO, Celia Maria Martinho de. Black freemasons and the enlightenment (Brazil, década de 1830). Artigo apresentado no Congresso sobre Iluminismo, promovido pela International Society for Eighteenth-Century Studies (ISECS), na Universidade da California, em Los Angeles, no período de 3 a 10 de agosto. 2003b. Não publicado. 
AZEVEDO, Celia Maria Marinho de. Anti-racismo e seus paradoxos: reflexões sobre cota racial, raça e racismo. São Paulo: Annablume, 2004a.

AZEVEDO, Celia Maria Marinho de. Onda negra, medo branco: o negro no imaginário das elites, século XIX. São Paulo: Annablume, 2004b.

BARATA, Alexandre Mansur. Maçonaria, sociabilidade ilustrada e independência (Brasil, 1790-1822). Tese (Doutorado em História)-IFCH, Universidade Estadual de Campinas, Campinas, 2002.

BARMAN, Roderick J. Brazil: the forging of a nation, 1798-1852. Stanford, California: Stanford University Press, 1988.

BASILE, Marcello Otávio. Ezequiel Corrêa dos Santos: um jacobino na Corte Imperial. Rio de Janeiro: FGV, 2001.

BOXER, C. R. Race relations in the Portuguese colonial empire, 14151825. London: Clarendon Press, 1963.

CAMPANHOLE, Adriano et al. Carta de Lei - de 25 de Março de 1824. In: CAMPANHOLE, Adriano et al. Todas as constituições do Brasil. São Paulo: Atlas, 1971. p. 581-602.

CARDOSO, Edson. Tarefas políticas. Irohin, Brasília, ano 9, n. 6, p. 2, ago./ set. 2004.

CARMICHAEL, Stokely; HAMILTON, Charles V. Hamilton. Black power: the politics of liberation in America. New York: Vintage Books: Random House, 1967.

CARNEIRO, Maria Luiza Tucci. Preconceito racial: Portugal e Brasil Colônia. São Paulo: Brasiliense, 1988.

CASTRO, Jeanne Berrance de. A milícia cidadã: a Guarda Nacional de 1831 a 1850. São Paulo: Companhia Editora Nacional, 1979.

CASTRO, Jeanne Berrance de. A Guarda Nacional. In: HOLANDA, Sergio Buarque de. História geral da civilização brasileira: o Brasil monárquico: t. 2. Rio de Janeiro: Bertrand Brasil, 1995. p. 274-296.

CASTRO, Hebe M. Mattos de. Das cores do silêncio: os significados da liberdade no sudeste escravista: Brasil século XIX. Rio de Janeiro: Arquivo Nacional, 1995.

CASTRO, Hebe M. Mattos de. Escravidão e cidadania no Brasil monárquico. Rio de Janeiro: Jorge Zahar, 2000. (Coleção Passo a Passo). 
CASTRO, Paulo Pereira de. A experiência republicana, 1831-1840. In: HOLANDA, Sergio Buarque de. História geral da civilização brasileira: o Brasil monárquico: t. 2: v. 2. 6. ed. Rio de Janeiro: Bertrand Brasil, 1995. p. 9-67. O CRIOULINHO. Rio de Janeiro: Typographia do Diario, de N. L. Vianna, 30 set. 1833.

CRUZ, Magno. Alcântara: o povo negro resiste. Irohin, Brasília, ano 9, n. 6, p. 21-23, ago./set. 2004.

DEGLER, Carl N. Neither black nor white: slavery and race relations in Brazil and the United States. Madison, Wisconsin: The University of Wisconsin Press, 1986.

DEGLER, Carl N. Nem preto, nem branco. Rio de Janeiro: Labor, 1976.

DELACAMPAGNE, Christian. L'Invention du racisme: antiquité et moyen age. Paris: Fayard, 1983.

DOUGLASS, Frederick Douglass. Citizenship and the spirit of caste: an address delivered in New York, New York, on 11 May 1858. In: BLASSINGAME, J. W. (Org.). The Frederick Douglass papers series one: speeches, debates and interviews: v. 2: 1847-58. New Haven: Yale University Press, 1979. p. 211-212.

FANON, Frantz. Peau noire, masques blancs. Paris: Seuil, 1971.

FLORY, Thomas. Race and social control in independent Brazil. Journal of Latin American Studies, v. 9, n. 2, p. 199-224, 1977.

FURET, François. O nascimento da História. In: FURET, François. A oficina da História. Lisboa: Gradiva, [s.d.]. p. 109-135.

GOULD, Stephan J. The mismeasure of man. 2nd. ed. New York: W. W. Norton \& Company, 1996.

GOULD, Stephan. A falsa medida do homem. São Paulo: Martins Fontes, 2000.

GRINBERG, Keila. O fiador dos brasileiros: cidadania, escravidão e direito civil no tempo de Antonio Pereira Rebouças. Rio de Janeiro: Civilização Brasileira, 2002.

O HOMEM DE CÔR. Rio de Janeiro: Typographia Fluminense de Brito e C., n. 1,14 set. 1833.

JACOB, Margaret. Living the enlightenment: freemasonry and politics in eighteenth-century Europe. London: Oxford University Press, 1991. 
LEBÉDEL, Claude. Chronology of the History of France. Rennes: OuestFrance, 1999.

LIBBY, Douglas Cole; PAIVA, Clotilde Andrade. Manumission practices in a late Eighteenth-Century Brazilian slave parish: São José d'El Rey in 1795. Slavery and Abolition, v. 21, n. 1, p. 97-127, April 2000.

MAIO, Marcos Chor; SANTOS, Ricardo Ventura. Política de cotas raciais, os "olhos da sociedade" e os usos da antropologia: o caso do vestibular da Universidade de Brasília (UnB). Horizontes Antropológicos, Porto Alegre, ano 11, n. 23, p. 181-214, jan./jun. 2005.

MILES, Robert. Racism. London: Routledge, 1989.

MONTEZUMA, Francisco. A opposição de 1831 e 1832 justificada ou os crimes da administração actual por um brasileiro amante de sua patria. Rio de Janeiro: Typographia do Diario, 1832.

MONTEZUMA, Francisco. A liberdade das repúblicas. Rio de Janeiro: Typ. do Diario de N. L. Vianna, 1834.

MOREL, Marco. O período das regências (1831-1840). Rio de Janeiro: Jorge Zahar, 2003.

MORISON, Samuel Eliot (Org.). Sources and documents illustrating the American Revolution 1764-1788 and the formation of the Federal Constitution. 2nd. ed. London: Oxford University Press, 1965.

MOURA, Clóvis. O negro nas lutas de emancipação do Brasil. In: MOURA, Clóvis. O negro, de bom escravo a mau cidadão? Rio de Janeiro: Conquista, 1977. p. 126-155.

OLIVEIRA, Cecília Helena Lorenzini de Salles. Nação e cidadania: a Constituição de 1824 e suas implicações políticas. Horizontes, v. 16, p. 11-37, 1998.

PAULA, Eurípedes Simões de. A organização do Exército Brasileiro. In: HOLANDA, Sergio Buarque de. História geral da civilização brasileira: o Brasil monárquico: t. 2. Rio de Janeiro: Bertrand Brasil, 1995. p. 265-277.

PINHO, P. Reinvenções da África na Bahia. São Paulo: Annablume, 2004. POLIAKOV, Leon. O mito ariano. Tradução de Luiz João Gaio. São Paulo: Perspectiva: Ed. da Universidade de São Paulo, 1974. 2 v.

SANTOS, Hélio. Para além das cotas. Irohin, Brasília, ano 9, n. 6, p. 11-13, ago./set. 2004. 
SERRÃO, Joel; MARQUES, A. H. Oliveira (Org.). Nova história da expansão portuguesa: o império luso-brasileiro, 1750-1822: v. 8. Coordenado por Maria Beatriz Nizza da Silva. Lisboa: Estampa, 1986.

SERRÃO, Joel; MARQUES, A. H. Oliveira (Org.). Nova história da expansão portuguesa: o império luso-brasileiro, 1750-1822: v. 7. Coordenado por Fréderic Mauro. Lisboa: Editorial Estampa, 1991.

SILVA, Maria Beatriz Nizza da. A estrutura social. In: SERRÃO, Joel; MARQUES, A. H. Oliveira (Org.). Nova história da expansão portuguesa: o império luso-brasileiro, 1750-1822: v. 8. Coordenado por Maria Beatriz Nizza da Silva. Lisboa: Estampa, 1986. p. 215-260.

SOARES, Carlos Eugênio L.; GOMES, Flávio. Sedições, haitianismo e conexões no Brasil: outras margens do Atlântico Negro. Novos Estudos: Cebrap, n. 63, p. 131-144, jul. 2002.

VENANCIO FILHO, Alberto. Francisco Gê Acaiaba de Montezuma, Visconde de Jequitinhonha, primeiro presidente do Instituto dos Advogados Brasileiros. Rio de Janeiro: IAB, 1984.

A VISCONDESSA de Jequitinhonha ao publico. Rio de Janeiro: Typ. Americana de J. Soares de Pinho, [s.d.]. 